\title{
Fate and Choice in Kieślowski's Blind Chance
}

\author{
By Yvonne Ng
}

Fall 2005 Issue of KINEMA

\section{FATE AND CHOICE IN KIEŚLOWSKI'S BLIND CHANCE}

FILM lovers who appreciate the cinema of the late Polish director Krzysztof Kieślowski (1941-1996) are likely to be familiar with his widely acclaimed works such as the Decalogue (1988), the series of mini-features made for Polish Television based on the Ten Commandments; the metaphysical beauty of The Double Life of Veronique (1991); and the Three Colours trilogy: Blue (1993), White (1993) and Red (1994), through which the director explores the concepts of liberty, equality and fraternity. Much less is known, however, of Kieślowski's numerous documentaries which started his career and of his early feature films which have yet to find commercial release in North America.

Kieślowski was a filmmaker who came to be regarded as a philosopher, poet and humanist. His work is deeply concerned with questions of an existential nature and with moral dilemmas faced by ordinary people. His view of human nature is honest but always compassionate. He considered himself among the weak and ignorant and often professed the Socratic sentiment that he was someone who didn't know, who was searching for answers. "My work is... motivated by the fact that I really want to understand, that I really want to see why things are the way they are."(1) This self-doubt and the search for meaning is reflected in his work: "All my films from the first to the most recent ones, are about individuals who can't quite find their bearings, who don't quite know how to live, who don't really know what's right or wrong and are desperately looking."(2)

Whether in documenting Polish social and political life under Communism, or in creating fictional characters, the individual and his predicament have always been central to the narrative. The director observed that while film had offered the best description of Polish life in the 1970s, he realized by the end of the decade that the limits of this description had been reached.. "A result of this train of thought is Blind Chance, which is no longer a description of the outside world but rather of the inner world. It's a description of the powers which meddle with our fate, which push us one way or another."(3) Since his documentary days, Kieślowski had tried to uncover what his characters thought and desired, and why they behaved the way they did. He said of his objective as a filmmaker, "This goal is to capture what lies within us, but there's no way of filming it. You can only get nearer to it." ${ }^{(4)}$

Like most of Kieślowski's earlier feature films, Blind Chance, the director's third full-length feature, is a technically straightforward production, devoid of special effects. It was completed in 1981 on the eve of martial law and was immediately banned. It was finally released in 1986 . Although not a political film, it nevertheless reflects the political reality of its time. Its significance lies in the philosophical exploration of chance in human existence, and the part we play in shaping our destinies through our ability to make conscious choices. However, more than just a fascinating account of how chance influences fate, Blind Chance brings up the question of how one ought to live. What follows, therefore, is a study of the filmmaker's reflection on the search for meaning in life and the nature of moral goodness through a close analysis of the film's remarkable narrative technique and its inter-related themes of chance, fate and choice.

\section{Chance: The Triple Life of Witek}

One reason why Kieślowski's films sometimes seem imbued with an inexplicable sense of mystery is due to his propensity to let chance play an important part in the lives of his characters, as it inevitably does in reality. This force, whose nature is beyond human control and comprehension, is what we sometimes also call luck, coincidence, or perhaps God's will. However we choose to call it, chance adds to the unfathomable in human existence, changing destinies for better or worse, in subtle and in dramatic ways. In one of the most provocative explorations of chance and fate in cinema, Kieślowski employs an original and powerful thought experiment showing how one simple, commonplace action could produce three distinct possibilities of one man's life.

The story revolves around Witek Dlugosz (Bogusław Linda), a medical student on leave of absence. Late for his train, Witek runs desperately after it as it leaves the station. In the first variant of his existence, 
Witek succeeds in catching the train, befriends a Communist and is inspired to become a Party member. In the second, he misses the train, scuffles with the railway guard, is arrested and sentenced to jail and community labour where he meets someone from the Opposition. Consequently, Witek joins the Opposition as an activist. In the third scenario, he misses the train but meets a girl from his medical school. They fall in love and get married. Witek leads a happy life as a husband and father. He also finds satisfaction in his career as a doctor, steering clear of politics. As he leaves the country on a work-related trip, his plane explodes.

While literature has a natural advantage over the audiovisual language in describing the intangible world of thoughts, emotions and intuition, film is the perfect medium for the unusual narrative structure of Blind Chance. Film's ability to portray external reality while manipulating time and space makes for an illuminating visual comparison of what can only be vaguely imagined: the three possible lives of one man. The subject is fascinating, for who has not, at one point or another, wondered what their lives might have been like if they had done this instead of that, or if a chance event had not happened, or perhaps if they had been born in another time or place?

Slavoj Žižek, the prolific Slovenian writer and philosopher, proposes that this narrative approach, employed by Kieślowski some twenty years ago, is prophetic in view of the arrival of the hypertext.

This perception of our reality as one of the possible - often even not the most probable - outcomes of an "open" situation, this notion that other possible outcomes are not simply cancelled out but continue to haunt our "true" reality as a spectre of what might have happened, conferring on our reality the status of extreme fragility and contingency, implicitly clashes with the predominant "linear" narrative forms of our literature and cinema - they seem to call for a new artistic medium in which they would not be an eccentric excess, but its "proper" mode of functioning. One can argue that the cyberspace hypertext is this new medium in which this life experience will find its "natural," more appropriate objective correlative, so that, again, it is only with the advent of cyberspace hypertext that we can effectively grasp what Altman and Kieślowski were effectively aiming at. ${ }^{(5)}$

As to the significance of the film's three different possibilities, film historian Annette Insdorf explains, "The fact that we see three versions rather than two means it is not a simple choice of one way of life versus another; rather it is open-ended, for where three versions exist, there can be four or more." ${ }^{(6)}$ However, the philosophical interest of this intriguing thought experiment is not only an exploration of how chance influences fate but also of how moral choice and personal responsibility determines who we are. At the same time, Kieślowski shows that making the right decisions is often neither obvious nor easy.

In Blind Chance, Witek is a young man in search of direction in life and who wants to do good. He is introduced to the viewer through a sequence of images preceding the three variations of his existence. The film opens with a close up of a man, whom we soon recognise to be the protagonist, seated in an aeroplane. As he looks into the camera, his eyes suddenly widen in horror as he screams a reverberating "No!" What follows is a series of seemingly unrelated images, possibly Witek's flashbacks ${ }^{(7)}$. These fragmented scenes provide a fleeting glimpse of his personal relationships from childhood to adulthood. Throughout the film, they serve as a point of reference, to be taken up and developed in the various versions of his life. ${ }^{(8)}$

\section{Liberty: Under no obligation}

Having barely caught the train in the first version, Witek soon befriends a middle-aged Communist veteran named Werner (Tadeusz Łomnicki). On the train, Witek notices an unkempt young man being roughhandled by the police in plainclothes. Following the young man to the washroom, Witek urges him to seize the opportunity to escape, and is surprised to find his offer of help ignored as the prisoner makes his way back to his captors. In this brief incident underlining the relationship between chance and personal choice, Werner tells the perplexed Witek, "Sometimes people don't escape. They don't want to."

In Warsaw, Witek follows Werner back to his apartment where he learns that the older man had been forced to confess to crimes he had not committed "for the Party's sake" and for which he had been subsequently imprisoned. Coincidentally, his lover, Krystyna, had a husband, Adam (Zbigniew Zapasiewicz), who was also arrested but on spying charges. The two men ended up in the same prison. As fate decreed, Adam was 
released before Werner, so that by the time the latter got out, Krystyna and her husband had resumed their married life together.

The first version of Witek's life shows not only the interplay of luck and chance in life but is notable for the sharp and insightful character portraits. Werner is kindly and slightly scruffy in appearance, and getting repetitive with age. He is, however, honest and still idealistic despite having suffered the injustice of the Communist Party. He expresses to Witek his hope that the younger man and his generation will perhaps manage to fix the system. Throughout the film, the viewer is presented with a consistent image of the protagonist as a compassionate and caring human being. Upon seeing the older man shiver with cold, Witek covers him with a blanket and spends the night in his sparsely-furnished apartment.

Having been told by his dying father that he was under no obligation ("nic nie musisz"), and interpreting this to mean that he could choose something other than a medical career, Witek's freedom to do as he pleases upon the death of a family member prefigures Julie's sudden "liberty" after the death of her husband and child in Blue. But whereas Julie tries to forget her past and to live without love or commitment, Witek seeks to define himself through commitment to a cause.

When Werner introduces Witek to Adam, now a rising Party functionary, we see that Adam is everything that Werner is not - the slick image of power and success, with a comfortable home and a wife whom Werner is in love. They also represent two contrasting types of Communist supporters: the ruthless opportunist and the romantic idealist. While discussing his 1975 documentary Curriculum vitae, Kieślowski said, "It's a generalization to say that Communists are bad and the rest of us are fantastic - it's just not like that. Communists, like us, are made up of those who are wise and others who are foolish, those who are good and others who are bad." ${ }^{(9)}$ Werner's faith in his political ideals is clearly genuine as he speaks to a group of young people about the need for a model to serve as a guiding light, for "without that ray of hope, that bitterness, life is a sorry experience." Witek is inspired by Werner's speech to join the Communist Party in the hope that it will enable him to improve his society. His decision angers Czuszka (Bogusława Pawelec) whom he has met again by chance and who is now his girlfriend. Unlike Witek's naive romanticism, Czuszka distrusts the Communist Party, an instinct that will soon prove to be justified.

At work, a Party official (Jerzy Stuhr) jumps at the chance to send Witek in his place to deal with a "mutiny" by the inmates of a drug rehabilitation centre. On arrival at the site, Witek discovers that the Party had replaced the centre's doctors with their own staff who are hated by the inmates for their heavy-handedness and lack of understanding. In protest, the institution's occupants have imprisoned the government personnel in a cage and are demanding the return of the original staff. Despite being caught in this potentially dangerous situation, Witek tries objectively to understand their point of view and is in fact sympathetic to their cause.

Seated among the youthful patients of the drug centre at a protest music session, Witek seems more like one of them than like a Party member, a subtle yet effective image of his shared desire with the "mutineers" for a world that is more just. Nevertheless, he does not forget the Party doctors locked up in the next room, and while the attention of the young people are being distracted by the music, Witek takes the opportunity to search for the key to the cage. He finds it and frees the prisoners. As the group makes their getaway, they are discovered by the inmates who promptly start to douse the building with gasoline. Without hesitation, Witek offers himself as a hostage while the Party personnel flee and is consequently locked in the cage. His captor, by a stroke of irony, is none other than the long-haired young man Witek had tried to help on the train. The young man, however, betrays no sign of the compassion that Witek had earlier shown him. Instead, after Witek phones the Party office to negotiate the inmates' demands, his captor suddenly throws a pail of liquid into the cage followed by a lit match. Horrified, Witek waits for an explosion that would burn him alive but nothing happens. The bucket contained only water - "a test run," the young man tells him coolly.

This dramatic episode underlines Witek's fundamental courage and sense of moral responsibility, in sharp contrast to the bumbling cowardice of the senior Party officials who had sent him to the drug centre in their stead. The aftermath of this incident also sheds light on Adam's self-serving principles in a conversation with Witek after the latter's ordeal.

Adam: You did well to show a moment's weakness. 
Witek: I was scared.

Adam: Yes, but it can also work in your favour. By faltering for a moment, you become like them...But it wasn't clever to say they were in the right.

Witek: They were.

Adam: But why say so in their presence? Never concede a case unless there's a percentage in it.

Witek: I was trying to be fair.

Adams: But you were there in a public capacity. You'd have behaved differently if you'd been there privately and on your own.

Witek: Why? I was on my own.

Adam: No. You had the phone and the authorities outside to fall back on.

Nowhere in their discussion does Adam show genuine concern for Witek's well-being even though the younger man has risked his life to do his job. He attempts to diminish Witek's role in the crisis by playing down the danger he was in and by crediting the Party for Witek's brave conduct.

Finished just before the introduction of martial law in 1981, the film seems prophetic in its prediction of Communism's imminent collapse. Unlike Werner, Adam is both a cynic and a realist. He tells Witek: "You can see for yourself that everything is falling apart. The people who run things are helpless. These structures are bound to crack. It's just a question of time." He, like Werner, points to Witek as someone capable of improving the system. However, Witek senses a price for accepting such responsibility: "What terrifies me is that a person has to forfeit his freedom. That you can be so dependent." Adam's matter-of-fact reply gives Witek a false sense of security: "That's what organisations are about. I know that in my position, I'm closely watched and I accept it."

At this point, Witek has little idea of the extent to which the morally corrupt system will affect not only his freedom but of those he loves. Neither does he realize how closely he is being watched by Adam himself. When Witek sees him in his boat harboured near the place where Samizdat publications are stored, he innocently remarks on the coincidence. Only when Adam questions him about Czuszka's role in the underground activity does Witek sense danger. When Czuszka is suddenly arrested, he realizes with a shock that he has been unwittingly turned into an informer, a development that destroys his relationship with her. He can no longer accept Werner's romantic idealization of the Communist doctrine but neither can he identify with the cynical opportunism of Adam. As he waits to board a plane for a conference in Paris with a group of Party members, they are told at the last moment that they will have to remain in the country to deal with strikes that have broken out. The first possible scenario of Witek's life thus ends on a note of frustration and disillusionment as he smashes a Party official's crystal vase in his custody.

\section{Equality: The opposition}

Part two begins with Witek making a mad dash for the departing train and knocking a glass of beer out of a tramp's hand in the process. He is stopped by a station guard and a scuffle develops. The police arrests him and takes him to court where he is sentenced to 30 days' jail and community labour. While working in a park one day, he meets another inmate, Marek (Jacek Borkowski), who has inadvertently dug up a bottle. Inside is a message written by a few college students in 1957 predicting their careers and positions in twenty years' time. As the two men ponder over whether these ambitions have been fulfilled, the audience is similarly reminded of the disparity that often appears between human aspiration and reality, leaving a question mark over Witek's chance of happiness in this variation of his existence.

This segment shows an alternative perspective of the mysterious forces that influence our lives: the belief that human events are determined by a higher purpose, God's Will, rather than by random chance. Marek, who is an Opposition activist, introduces Witek to Stefan (Adam Ferency), a wheelchair-bound priest who is also involved in underground work. Looking at his new-found friend, Witek is moved to remark, "Imagine! If a month ago I hadn't missed a train, I wouldn't be with you here now." To which Stefan responds, "It isn't wholly a matter of chance." Witek replies sceptically: "Sometimes I think it is."

On an assignment to visit the home of a woman dissident, as he approaches her building, Witek hears a commotion coming from her apartment and the noise of furniture being overturned. A few men, presumably sent by the authorities, leave the building smirking and laughing. Upon entering the flat, Witek discovers a middle-aged woman on the floor of her ransacked apartment appearing astonishingly unperturbed by the 
attack. She explains she is not afraid because she believes God has made her a gift of life. Twelve years ago, she was told by doctors she had only three years to live. She quotes Mother Teresa who said that the one thing you can give a person half an hour before death is the belief that you are not completely alone. To her, Witek's timely arrival is a sign of divine Providence.

Deeply impressed by the woman's tranquil faith in God, Witek decides to be baptized and become a Catholic. Once again the romantic idealist, he yearns to improve his society, not by joining the Party, "The answer's not there," he tells Stefan enigmatically, but by adopting the religious and political beliefs of those whose courage and conviction he admires, such as the priest himself and the woman whom he had visited. Like Czuszka in Part One, he now becomes involved in the printing of dissident publications. Among his underground colleagues is Staszek, the medical school Dean's son who will be the indirect cause of Witek's fate in the third version of his life.

In Part Two, Witek's essential decency is underscored when he applies for a passport to attend a gathering of Catholic youth in Paris. The authorities tell him he will be given one on condition that he provides them with information on certain individuals in Paris. Rather than being an informer, as he was trapped into becoming in Part One, Witek chooses not to go. Shortly after this, at an underground meeting which he helped organise, Witek is surprised to see his boyhood friend Daniel, who was forced to emigrate to Denmark with his father in the late 1960s because they were Jews. Daniel is back in Poland to attend his mother's funeral. With him is his sister Vera (Marzena Trybała), now married. As a result of this chance meeting, an affair develops between Witek and Vera.

In many ways, the first two versions of Witek's life are mirror images of each other, with elements from the first episode carefully reflected in reverse in the second. If White is about "equality understood as a contradiction," (10) the idea that people do not really want equality but rather want to be more equal than others, the first two episodes of Blind Chance may be understood as diametrically opposed scenarios leading - ironically - to similar conclusions. In Parts One and Two, Witek is committed on opposite sides in political and religious belief but ultimately, both possibilities find him equally trapped by disillusionment. In Part One, Witek insists on knowing everything about Czuszka, including her past relationships, only to discover he cannot bear to hear the whole truth. In Part Two, after a long talk during Vera's visit to his home in Lodz, Witek naively remarks, "We must have said all there is to say." She replies, echoing the director's own belief, "I doubt it. There are too many things you can't tell another person." As it turns out, her words will have ominous significance in the events to follow.

After Vera returns to Warsaw, Witek is shocked to discover that the printing shop has been raided in his absence and his colleagues arrested. Not surprisingly, Marek holds him responsible and suspects him of betrayal. Even Stefan seems to think he is responsible. Out of either desperation or instinct, Witek goes to Warsaw in search of Vera. At a bus stop, he meets Werner from Part One and asks for directions to her home but she is not there. ${ }^{(11)}$ Upon returning home, he finds a message from Vera saying she had waited hours there for him. In this variation, Witek, like Czuszka, finds himself betrayed and can only conjecture that Vera had something to do with it. When Witek's aunt blithely remarks that many Jews were "magnificent Communists," the audience realizes that Vera had probably been the cause of Witek's trouble, perhaps in a similar way he had unwittingly given away Czuszka.

Fraternity: Greater love has no man...

In Part Three, Witek misses the train but meets Olga (Monika Godzik), a fellow student from the medical school, who has come to see him off. Happily for Witek, in failing to catch his train, he finds love and fulfilment instead, both in his personal and professional life. He returns to medical school, marries Olga and soon becomes a father. In keeping with his character and personality in the first two versions, he proves to be a loving husband and father, and a compassionate doctor. In this variation, however, Witek is decidedly apolitical and an atheist.

Witek confides in the Dean (Zbigniew Hübner) about the Party's offer of a tenure which he decides to refuse because he has no interest in committing himself politically. Although he does not believe in God, he will use religion as an excuse not to join the Party. Similarly, when he is asked to sign a petition against the arrest of students involved in Samizdat and other dissident activities, Witek refuses. He also learns that the Dean has not signed, presumably to remain impartial, because his son is involved. Witek's refusal to remain 
apolitical, Kieślowski hints, is due to the very human fear of jeopardizing his career and personal happiness, even if Witek does not see or admit this to himself. One of the petitioners understands this, telling him "It's no crime to be afraid." This remark leaves Witek thoughtful and restless.

That evening, Witek receives a call from the Dean who informs him that he will not be able to lecture in Libya on account of his son's arrest. Witek agrees to give the lecture in his stead even though he may be penalised by the authorities for it. The viewer suspects that Witek's decision is the result of an implicit determination to overcome his fear and to take a stand against injustice as much as to help his colleague. He postpones his flight in order to celebrate his wife's birthday, buying a ticket that will fly him to Libya via Paris.

After her birthday dinner, Olga is in a melancholic mood. As if seized by a premonition, she begs her husband not to go on the trip. Taken aback, Witek informs her that his mind is made up. At the train station, Olga surprises Witek with an announcement that they will soon have a daughter and asks him to write her his thoughts. On arrival at the airport, Witek sends his wife a note, not knowing they will be his last words to her.

In the last sequence of Blind Chance, the director links characters from the three parts of the film together, foreshadowing the technique in the ending of Red when characters from White and Blue also come together. At the end of Part Three, the audience sees the same female airline attendant from Part One checking documents for the Communist Party members. Stefan the priest and his group of Catholics from Part Two are chatting and getting ready to board the same plane as Witek. The audience's ability to identify the various characters endows us with a pleasant illusion of omniscience as we know how their lives might have intertwined with Witek's had events taken a different turn. We realize that Witek, in the other two variations of his life, would also have been on the same flight as in Part Three had chance not intervened in each case. In the final scene, Witek finally gets on board the plane. Moments after take-off, the plane blows up in flames.

\section{Beyond the concrete}

Never overtly religious, Kieślowski's films nevertheless often have a spiritual and metaphysical quality that comes from his preoccupation with the mysterious. His films reveal a deep awareness of and sensitivity to that dimension of life which influences human events, yet for which there is no rational explanation: "The realm of superstitions, fortune-telling, presentiments, intuition, dreams, all this is the inner life of a human being and all this is the hardest thing to film." ${ }^{(12)}$

In Blind Chance, the theme of presentiment permeates the film. In Part One, after his encounter with Adam at the harbour, Witek gets drunk on vodka, as if trying to numb a feeling of foreboding. In Part Three, Olga suddenly entreats Witek not to go on his trip. The film's "quirky details"(13), as Insdorf calls them, are interesting not only for providing the film with spontaneity but also for their ability to suggest Witek's particular predicament in each version of his life. For example, in the first variation, when Witek watches a slinky move down a flight a steps and come to a stop, his comment that "It's like it's died" seems to foreshadow the end of his own hopes and ideals in the Communist Party. In Part Two, the bottle containing a message alludes to the distance between hope and reality. Similarly, when Witek visits the priest and sees a garish image of Christ on the wall with eyes that give the illusion of opening and closing, the picture's gimmickry seems to hint at the unauthenticity of Witek's engagement with the Catholic faith. In Part Three, while visiting the home of a patient, Witek comes across two jugglers skilfully keeping a mind-boggling number of balls in the air. When he casually attempts to juggle apples at home, not surprisingly without success, the challenge of keeping his personal happiness in balance is further amplified for the audience.

In his quest for truth, Kieślowski explores the complexities of life with originality, subtlety and depth. Part of the power and delicacy of his films is his ability to delineate the invisible, mysterious dimension of human existence. He would have understood the exhortation of Jesuit playwright Ernest Ferlita: "To be open to mystery...the experience of film at its deepest level prompts that response"(14)

\section{Form, Chance and Choice}

It has been noted that Blind Chance was probably the inspiration for the British feature Sliding Doors (1998) by Peter Howitt, a romantic comedy starring Gwyneth Paltrow. The latter film, however, reduces both the 
structure and ideas of Blind Chance and The Double Life of Veronique to a contrived and superficial story about the heroine's love life and career. It is interesting to note that The Double Life of Veronique seems to be a continuing experiment on the idea of essentially identical characters living parallel lives in different places. Also significant is the fact that the three-part structure and the themes of chance, fate and choice in Blind Chance would be reworked in meaningful ways in the Three Colours trilogy. ${ }^{(15)}$

Blind Chance is formally structured. It opens with a kind of prelude comprising a series of seemingly unrelated images before going on to develop three possible variations on the theme of one man's destiny. The three versions always start the same way, with Witek running through the train station desperate to catch his train to Warsaw. The repetitions and variations of this compact narrative enables the director to exploit, as one reviewer notes, "this potential for setting up comparisons, irony and unexpected connections to the full."(16) This Kieślowski does with consummate skill, displaying as always, an uncanny ability to create convincing characters and situations, and to surprise. All three versions of Witek's lives feature mentors who replace his dead father: Werner, the idealistic Communist in Part One; Stefan the priest and dissident leader in Part Two and the Dean of the Medical School in the Part Three. In each version, Witek is separated from the woman he loves, twice as a result of his political commitment and finally by death. In each episode an incident occurs which compels him to take a moral stand and reconsider his beliefs. Three times he unsuccessfully attempts to fly out of the country.

Insdorf also notes "a pattern of displacement" throughout the film ${ }^{(17)}$ : Witek, by virtue of having been born first, is alive in place of his twin who had died at birth. Later, the successful Party functionary, Adam, says of Werner: "If he'd been let out earlier, he'd have been in my shoes and I in his." Whereas Werner takes the place of Witek's father, Witek replaces the doctors in the cage. In Part Two, Witek becomes an opposition activist like Czuszka in the first story and in a double stroke of irony, finds himself not only accused of betrayal to the dissident cause but also a victim of what seems to be unwitting betrayal by his Communist lover. In Part Three, Witek chooses to substitute for the Dean and dies in his place as a result, paying for his decision with his life.

In Blind Chance as in many of his films, the director holds the existentialist view that the heart of the human condition lies in having to make decisions without ever really knowing what the correct choices are. Nevertheless, it is our duty to bear full responsibility for the consequences of our actions. Whichever path we take leads ultimately to a common destiny. According to the director, "The third ending is the one which means the most to me - the one where the aeroplane explodes - because one way or another, that's going to be our fate. It's all the same whether this happens in an aeroplane or in bed, it doesn't matter." (18)

Although death is ultimately everyone's fate, Witek's premature death has an air of inevitability that is the result of a deeper significance. Explaining why the hero of his next film No End (1984) is already dead at the beginning of the film, Kieślowski says, "People like that, people with such clear consciences and such clean hands don't stand a chance any more. Now, how do you show that they don't stand a chance? You show that they're not there any more. They have to die... That their purity and clarity brought into collision with these times has to end with their disappearance."(19)

Annette Insdorf suggests that although the director was never comfortable with the term, Blind Chance is in the tradition of the "Cinema of Moral Anxiety", the Polish film movement which emerged in the 1970s "whose central theme was the isolation experienced by persons of integrity in a corrupt and dishonest society."(20) Indeed, the film is an undeniably bleak portrait of one man's existential struggle to find hope and meaning within a morally bankrupt and dehumanizing system. In all three versions of his life, Witek is invariably the same idealistic, decent, human being. In each case, he wants to commit himself to a meaningful cause and in his desire to do what is right, unwaveringly chooses to be morally responsible. In Part One, for example, Witek risks his own life by offering himself up to the rebels when they threaten to torch the drug rehabilitation centre with everyone in it. His actions are fuelled by a fundamental concern for the welfare of others. Even in Part Three, where he has few political illusions, he is no less idealistic in friendship, willing to risk his personal interest to do the Dean a favour. In his good-heartedness, Witek is the precursor of Valentine in Red, who, more than any other character in Kieślowski's films, has come to symbolise fraternal love.

The potency of the film's narrative and characterization is a result of the director's understanding of human 
nature and the nature of reality. As the director observes: "But often, even when we know what is honest and the right thing to do, we can't choose it. I believe we are not free...we're constantly imprisoned by our passions and feelings. You can't get rid of this. It makes no difference whether you've got a passport which allows you into every country or only into one and you stay there. It's a saying as old as the world - freedom lies within." (21) By this token, although unable to escape the politically oppressive borders of Communist Poland, Witek is close to being free in the most profound sense of the word.

Throughout the film, at each critical juncture when he is obliged to make with an existential choice, Witek finds the courage to overcome his fears and desires to do what is just and humane. Given the complexity of life which time and again gives rise to conflicts between subjective hope and objective reality, Witek is also faced with the frustration of seeing his ideals and good intentions subverted, and even worse, produce harm. A case in point is his desire to improve his society by joining the Party only to find himself turned into an informer. Even then, when it would have been more advantageous for him not to do anything about it, he reacts with moral integrity by rebelling against the manipulation of the opportunistic Party functionary Adam.

In the 1995 Danish television documentary I'm So-So by Krzysztof Wierzbicki, Kieślowski asserts, "We are a sum of several things, including individual will, fate (but we can change fate a little), and chance, which is not so important. It's the path we choose that is crucial." By showing the consistency with which Witek behaves in all three versions of his life, Kieślowski suggests that our sense of identity, which is inextricably tied to the meaning we give to human existence, is defined not so much by biographical details but by how we live and conduct ourselves in everyday affairs. Our choices define who we are. In the discerning words of the Belgian poet and playwright Maurice Maeterlinck, "Many a happiness in life, as many a disaster, can be due to chance, but the peace within us can never be governed by chance."

\section{Notes}

1. Danusia Stok (ed. and trans.), Kieślowski on Kieślowski, (London: Faber and Faber, 1993), p. 196.

2. Ibid., p. 79 .

3. Ibid., p. 113. 4. Ibid., p. 194.

5. Slavoj Žižek, "Run Isolde Run", Lacanian Ink. http://www.lacan.com/lacinkXVII5.htm, 7December 2001.

6. Annette Insdorf, Double Lives, Second Chances: the cinema of Krzysztof Kieślowski (New York: Hyperion, 1999), p.58.

7. Ibid., p.53.

8. For a description of the twelve images, see Annette Insdorf, Double Lives..., p. 54.

9. Kieślowski on Kieślowski, p. 58

10. Ibid., p. 217.

11. Similar "connections" of characters from different episodes can also be found in Kieślowski's later films, such as The Decalogue and Three Colours trilogy.

12. Kieślowski on Kieślowski, p. 194.

13. Insdorf, p.58.

14. Ernest Ferlita, "Film and the Quest for Meaning," Religion in Film, ed. John R. May and Michael Bird (Knoxville: The University of Tennessee Press, 1982), p. 131.

15. Insdorf, p.60.

16. Gareth Rees, "Przypadek" (1982), http://reviews.imdb.com/Reviews/28/2814, 02/10/00.

17. Insdorf, p.58. 18. Ibid., p. 113. 19. Ibid., p. 134. 
20. David A. Cook, A History of Narrative Film, (New York: W. W. Norton \& Company Inc, 1996), p. 695.

21. Kieślowski on Kieślowski, p.150.

\section{References}

May, John R. and Michael Bird (eds). Religion in Film. Knoxville: The University of Tennessee Press, 1982. Insdorf, Annette. Double Lives, Second Chances: the cinema of Krzysztof Kieślowski. New York: Hyperion, 1999.

Stok, Danusia (ed. and trans.). Kieślowski on Kieślowski. London: Faber and Faber, 1993.

"Interview with Kieślowski from Web". http://www.petey.com/kk/intrview.txt, 2 October 2000.

Miczka, Tadeusz. "Krzysztof Kieślowski's Art of Film". Kinema No. 7, Spring 1997, 23-45.

Rees, Gareth. Przypadek (1982). http://reviews.imdb.com/Reviews/28/2814, 2 September 2005.

Vorndam, Jeff. Blind Chance aka Przypadek.

http://www.aboutfilm.com/movies/b/blindchance.htm, 4 September 2005.

Žižek, Slavoj. "Run Isolde Run". Lacanian Ink.

http://www.lacan.com/lacinkXVII5.htm,7 September 2005.

\section{Author Information}

Yvonne NG is the co-author of Latent Images: Film in Singapore Second edition (NUS Press, 2010); Latent Images: Film in Singapore (OUP, 2000) and Latent Images: Film in Singapore CD-ROM (Singapore, 2003). She has written on Singapore and Asian cinema and contributes to the International Film Guide. 